\title{
Projekt etnograficzny: Mapa Obrzędowa Górnego Śląska
}

\author{
An ethnographic project: \\ Map of the Rites of the Upper Silesia
}

\section{Geneza powstania projektu wraz z jego charakterystyką}

Projekt Mapa Obrzędowa Górnego Śląska (dalej: Mapa) to etnograficzna inicjatywa badawcza podjęta przez Regionalny Instytut Kultury w Katowicach (obecnie Instytut Myśli Polskiej im. Wojciecha Korfantego) w latach 2017-2018. Jej założeniem było zbadanie współczesnej kondycji górnośląskiej obrzędowości dorocznej wraz z próbą oszacowania jej pozostałości w praktykach kulturowych mieszkańców Górnego Śląska. Zależało nam także na tym, aby przyjrzeć się nowym ${ }^{1}$ formom kulturowym pielęgnowanym lokalnie oraz dotrzeć do tradycji dotąd nierozpoznanych.

Kierowało nami przekonanie, że nastał właściwy czas na uzupełnienie dotychczasowych badań nad zwyczajowością i grupami obrzędowymi. Zdawaliśmy sobie sprawę z faktu, że ówcześnie nie było pełnego zasobu wiedzy na temat stanu tych zjawisk w interesującym nas regionie. Dynamiczna rzeczywistość zachęcała do nieustannego badania, dokumentowania i analizowania zmian oraz aktualnych tendencji. Gdy rozpoczynaliśmy realizację projektu, nie istniała inicjatywa, która objęłaby badawczo teren Górnego Śląska w granicach państwa polskiego możliwie kompleksowo

1 Np. Orszak Trzech Króli. Pierwszy orszak pojawił się na ulicach Warszawy w 2009 r., natomiast w kolejnych latach orszaki zaczęto organizować także w innych miejscowościach. 
i przekrojowo. Ponadto naszym zamiarem było, aby planowane do pozyskania materiały udostępnić w sposób atrakcyjny dla współczesnego odbiorcy.

Zanim jednak przedstawimy, czym Mapa jest, z jakich elementów się składa i jakie jest jej aktualne oblicze, warto zarysować drogę, którą przebyliśmy, i wskazać wcześniejsze doświadczenia, które doprowadziły nas do długoterminowego zainteresowania górnośląskim dziedzictwem. Rejestracja fotograficzna i filmowa nakierowana na wychwycenie często lokalnych i mało znanych wydarzeń w roku obrzędowym oraz ukazanie ich w przystępnej, popularnonaukowej formie, przyświeca bowiem naszym działaniom od wielu lat.

Pierwszą znaczącą inicjatywą dokumentacyjną był realizowany w latach 2007-2008 projekt Regionalny Wirtualny Album Obrzedowy prezentujący w formie kilkuminutowych materiałów filmowych kilkanaście zwyczajów pielęgnowanych w różnych częściach województwa śląskiego. Kolejnym działaniem było wydanie publikacji albumowej Świat obok nas. Obrzędowość doroczna w województwie śląskim, wskazującej najważniejsze, najbardziej charakterystyczne, ale też mało znane zwyczaje i obrzędy doroczne występujące na terenie województwa śląskiego² (Garstka 2013). Wartością tej pracy była i jest dokonana dla tych obrzędów i zwyczajów dokumentacja fotograficzna, będąca ważnym elementem etnograficznego opisu, co nie zawsze w literaturze przedmiotu miało miejsce. Wśród tych zwyczajów wymienić można: grupy kolędnicze tzw. szlachcice z Beskidu Żywieckiego, Turki (straże grobowe) z Koziegłówek, misie z gminy Niegowa, wodzenie niedźwiedzia we wsiach powiatu lublinieckiego, „pękanie skał” w Leśniakach, fakle w Stanicy, śmiergusty z Wilamowic, stawianie moja w gminie Jasienica, wygrywki z Brennej, Święto Ogniowe w Żorach, Wawrzyńcowe Hudy w Ujsołach, ziele w Ślęzanach czy kwietne kobierce z ziemi raciborskiej, układane na trasie procesji podczas uroczystości Bożego Ciała.

W latach 2014-2016 zespół, którego byliśmy członkami, przeprowadził badania zogniskowane wokół Zagłębia Dąbrowskiego (Małopolska Zachodnia)³, zrealizowane w projektach: Tropem Kolberga - etnograficzne badania terenowe Zagłębia Dąbrowskiego oraz Tropem badaczy Zagłębia Dąbrowskiego, których inicjatorem był Regionalny Instytut Kultury w Katowicach. Ten ciekawy, lecz trudny dla badacza teren ${ }^{4}$, np. z uwagi na nieliczne źródła pisane oraz wcześniejsze wyrywkowe i niewy-

2 Województwo śląskie składa się w większości z historycznych ziem śląskich i małopolskich, stanowiąc o wielokulturowości tego obszaru. Zagłębie Dąbrowskie, ziemia żywiecka oraz częstochowska, będące częścią województwa śląskiego, znajdują się poza obszarem Górnego Śląska.

3 Zagłębie Dąbrowskie znajdujące się w większości w województwie śląskim, położone jest poza obszarem Górnego Śląska, będąc częścią historycznej Małopolski. Niektórzy regionaliści do Zagłębia Dąbrowskiego zaliczają także Olkusz wchodzący w skład województwa małopolskiego.

4 W odniesieniu do obszaru Zagłębia Dąbrowskiego funkcjonują dwie koncepcje ujmowania jego granic Wąska z miastami Sosnowiec, Dąbrowa Górnicza, Będzin, Czeladź, Wojkowice oraz szeroka, skoncentrowana na terenie miast Sosnowca i Dąbrowy Górniczej, powiatów będzińskiego, zawierciańskiego, myszkowskiego i olkuskiego oraz gminy Ożarowice w powiecie tarnogórskim. 
starczające badania terenowe, został opisany w publikacji Tropem badaczy Zagłębia Dąbrowskiego (Garstka, Gawlik, Skonieczna-Gawlik 2016)

Już wówczas zastanawialiśmy się nad kolejnymi działaniami. Ukierunkowanie się na historyczną ziemię górnośląską było stosunkowo naturalnym wyborem.

W latach 2015-2016 Robert Garstka przeprowadził wstępne rozpoznanie dotyczące występowania w terenie interesujących nas zjawisk kulturowych, kontaktując się np. z sołtysami, księżmi, regionalistami i jednostkami kultury na terenie województwa śląskiego i opolskiego, dopytując o lokalne tradycje i zwyczaje. Równocześnie analizował dostępne źródła pisane, w tym te zamieszczone w internecie. W tym czasie nawiązaliśmy kontakt z Bogdanem Jasińskim - etnografem z Muzeum Wsi Opolskiej w Opolu. Korzystając z jego wiedzy i doświadczenia, jeszcze przed realizacją projektu Mapa, w 2014 i 2015 roku w wielu miejscowościach rejestrowaliśmy np. zwyczaje ostatkowe - obchód z kozłem i wodzenie niedźwiedzia (bera) ${ }^{5}$, tak charakterystyczne dla tego regionu. W pracach tych brała także udział Izabela Jasińska - pracownik Muzeum Śląska Opolskiego. Współdzielenie pasji i swoiste dojrzewanie do zajęcia się górnośląskimi zwyczajami i obrzędami dorocznymi doprowadziło ostatecznie do podjęcia szeroko zakrojonych prac badawczych.

Interesował nas obszar Górnego Śląska znajdujący się obecnie na terenie Rzeczypospolitej Polskiej, w granicach administracyjnych dwóch województw: śląskiego i opolskiego, część złożona z ziem zróżnicowanych geograficznie, historycznie, a przede wszystkim kulturowo. To unikatowy tygiel, w którym współistnieją i mieszają się odmienne tradycje - prawdziwy fenomen wielkiego bogactwa i niezwykłej trwałości kulturowego dziedzictwa.

Wytyczony przez nas obszar badań mieści się w historycznych granicach Górnego Śląska ustanowionych już w 1485 roku przez ówczesnego władcę Czech (i Śląska) króla Macieja Korwina, który podzielił Śląsk na Górny (leżący w górnym biegu Odry) i Dolny (w dolnym biegu). Dla każdej części ustanowił urząd starosty generalnego podlegający sejmowi krajowemu jako zgromadzeniu ustawodawczemu. Te królewskie akty położyły podwaliny pod górnośląską samorządność i tożsamość. Odtąd zaczęły się uwidoczniać, i z biegiem czasu ugruntowywać, kulturowe odrębności, które pogłębiały się i różnicowały, tworząc ogromnie pojemny i fascynujący zbiór tradycyjnych zachowań, rytuałów i obrzędów. To właśnie one stanowiły przedmiot naszych etnograficznych penetracji.

Podkreślamy jednocześnie, że w tym górnośląskim zbiorze staramy się dostrzegać zwłaszcza odrębności tzw. Śląska Opolskiego i Śląska Cieszyńskiego. Zauważyliśmy bowiem, że mieszkańcy tych subregionów silnie manifestują swoją odrębność względem Górnego śląska, którego historycznie są częścią. Ponadto podczas

5 Zwyczaj wodzenia niedźwiedzia na Śląsku Opolskim w 2019 r. został wpisany na Krajową listę niematerialnego dziedzictwa kulturowego. 
badań konsekwentnie przestrzegaliśmy „historyczności”, ponieważ spora część obecnego województwa śląskiego, to ziemie małopolskie. Nieuprawnione jest zatem stawianie znaku równości między pojęciem Górny Śląsk a województwo śląskie.

Czas na charakterystykę Mapy z naszej, badaczy perspektywy. Projekt opierał się na dokumentacji fotograficznej i filmowej obrzędów dorocznych oraz na wywiadach kwestionariuszowych dotyczących już tylko wyselekcjonowanych przykładów:

1. układanie dywanów kwietnych w Boże Ciało (Cyprzanów - gm. Pietrowice Wielkie; Racibórz, Klucz i Olszowa - gm. Ujazd; Zalesie Śląskie - gm. Leśnica);

2. pieszych i konnych procesji agrarnych (Świbie - gm. Wielowieś; Szałsza - gm. Zbrosławice; Bieńkowice - gm. Krzyżanowice; Borki Małe - gm. Olesno; Sternalice-gm. Radłów; Racibórz-Sudół);

3. wielkotygodniowego klekotania itragaczykowania (Borucin i Pietraszyn - gm. Krzanowice; Racibórz-Sudół; Strzeleczki - pow. krapkowicki; Poborszów - gm. Reńska Wieś);

4. karnawałowego wodzenia niedźwiedzia (Miedary-gm. Zbrosławice; Kochanowice - pow. lubliniecki; Krępna-gm. Zdzieszowice; Raszowa-gm. Leśnica; Daniec - gm. Chrząstowice);

5. tradycje związane z kultem św. Mikołaja (Borki Małe - gm. Olesno; Łąka - gm. Pszczyna; Krzanowice - pow. raciborski).

Wywiady przeprowadzane były za pomocą specjalnie opracowanych kwestionariuszy dostosowanych do specyfiki obrzędu. Rozmowy odbywaliśmy z uczestnikami i organizatorami tych wydarzeń oraz przedstawicielami lokalnych społeczności. Wywiady realizowane były w czasie bliskim występowania danego zwyczaju, tak aby refleksja informatora sprzyjała uzyskaniu jakościowych danych. Wspomniane praktyki kulturowe badano w kilkudziesięciu miejscowościach. Wybór zwyczajów motywowany był kilkoma powodami:

- powszechnością ich występowania (np. wodzenie niedźwiedzia);

- reprezentowaną unikatowością (np. Mikołaje z Borek Małych);

- znaczeniem dla lokalnych społeczności, również w wymiarze sakralnym (np. kwietne dywany, procesje, klekotanie).

Uzupełnieniem prac badawczych była kwerenda archiwalna (instytucjonalna i prywatna) zmierzająca do pozyskania fotografii z lat wcześniejszych, co ułatwiło ukazanie skali zmian w praktykach obrzędowych, jakie zaszły na badanym terenie. Do współpracy zostali zaproszeni doświadczeni etnografowie z muzealnych placówek partnerskich - Muzeum Wsi Opolskiej, Muzeum Śląska Opolskiego, Muzeum w Raciborzu i strategicznego kooperanta - Muzeum Śląskiego w Katowicach. Zaangażowanie profesjonalnych badaczy do projektu było nie tylko gwarantem odpowiedniego standardu pracy, ale okazało się integrującym działaniem, którego efekty widoczne są w aktualnych poczynaniach badawczych.

Wspomniana dbałość o prezentację wyników badań i prac dokumentacyjnych w sposób możliwie przystępny, skłaniała nas do refleksji dążącej do popularyzacji 
w interesującej formie pozyskanej wiedzy i materiałów. Mapa okazała się właściwym wyborem. Przede wszystkim dlatego, że jest obrazowa, wskazująca na nasycenie zjawisk kulturowych na konkretnym obszarze. A ponieważ jest wirtualnym narzędziem, to skala jej oddziaływania wzrasta. Mapa daje także obraz terenu, który wymaga dalszych eksploracji badawczych, pogłębiających dotychczasowe prace dokumentacyjne. Ponadto zaprojektowana funkcjonalność mapy daje możliwość wyszukiwania informacji: poprzez miejscowość lub wybrany obrzęd.

Mapa, w momencie powstania w 2018 roku, była prostą, acz pionierską ilustracją dorobku górnośląskiej „kultury obrzędowej”. Niech jednak nikogo nie zwiedzie jej „prosty” format. Nie istniała bowiem do owego czasu wirtualna baza danych, z której można by zaczerpnąć obrys historycznego Górnego Śląska leżącego w granicach Polski. Ta praca została wykonana siłami współpracowników Instytutu Myśli Polskiej im. Wojciecha Korfantego jako żmudne wielotygodniowe zajęcie. Dostęp do niej znajduje się pod adresem www.mapaobrzedowa.pl. Mapa zawiera aktualnie ponad 370, przypisanych do konkretnych miejscowości, udokumentowanych obrzędów i zwyczajów, które na bieżąco są aktualizowane. Każdy wpis na mapie opatrzony jest opisem obrzędu lub zwyczaju oraz licznymi fotografiami ilustrującymi je w wymiarze współczesnym i/lub archiwalnym W kilkudziesięciu miejscach na mapie zamieszczono ponadto kilkuminutowe materiały filmowe ukazujące przebieg danego zwyczaju i jego specyfikę wraz z komentarzem etnologicznym, stanowiąc materiał edukacyjny i popularyzatorski. Docelowo mapa ma stać się repozytorium wiedzy o obrzędowości dorocznej na Górnym Śląsku.

Zależało nam na tym, aby miała ona także społeczny wymiar, który realizowany jest poprzez możliwość współtworzenia zasobów mapy. Każda organizacja, instytucja czy osoba prywatna, która posiada archiwalne i współczesne fotografie obrazujące konkretny obrzęd (zwyczaj), może skontaktować się z Instytutem i przekazać je do umieszczenia na mapie. Służy temu zakładka na stronie projektu - „Twórz mapę”. Po wysłaniu materiałów są one analizowane pod względem spójności ze specyfiką mapy oraz pod względem merytorycznym. Wzbogaca to już istniejące wpisy na stronie, a w niektórych przypadkach wprowadza nowe miejscowości i występujące tam zwyczaje. Przyznajemy jednak, że ten społeczny wymiar wymaga zdynamizowania. To dla nas wyzwanie na kolejne miesiące. Zachęcamy lokalne społeczności do przekazywania posiadanych zbiorów Instytutowi. Obecność na mapie to także element promocji dla konkretnych miejscowości i wspólnot pielęgnujących dany zwyczaj.

Mapa jest projektem opowiadającym o górnośląskim bogactwie kulturowym, osadzonym w niematerialnym dziedzictwie tej ziemi, przejawiającym się w działaniach obrzędowych przynależnych lokalnym społecznościom. Projekt to jednak nie tylko wirtualna mapa. Powstała także mobilna wystawa fotografii mogąca służyć mieszkańcom i organizacjom kulturalnym jako materiał edukacyjny. Efektem projektu jest również publikacja Czas niezwykły. Obrzędowość doroczna na Górnym Śląsku (Garstka, Lysko 2018). Na prawie 280 stronach opisano ponad 60 obrzędów i tradycji wraz z bogatą 
dokumentacją fotograficzną (współczesną i archiwalną), w wielu przypadkach po raz pierwszy opublikowaną. Celowym zabiegiem było wprowadzenie do niej dużej liczby zdjęć, co pozwala zapoznać się (np. młodemu odbiorcy) z przykładami obrzędów, niejednokrotnie nieznanych i unikatowych. Książka jest wynikiem długoletnich badań terenowych, systematycznej obecności w środowisku, współpracy z jednostkami kultury i lokalną społecznością. Tekst w niej zawarty powstał na bazie współczesnej obserwacji terenowej i jedynie częściowo opiera się na wcześniejszych pracach uznanych badaczy zajmujących się np. obrzędowością doroczną na Górnym Śląsku.

Należy bowiem zaznaczyć, że w minionych kilkudziesięciu latach ukazało się niewiele opracowań książkowych aspirujących do całościowego omówienia obrzędowości dorocznej na Górnym Śląsku w granicach obu wspomnianych województw. Bodaj jedną z ostatnich ${ }^{6}$ jest praca Jerzego Pośpiecha pt. Zwyczaje i obrzędy doroczne na Ślasku (Pośpiech 1987). Do tego opracowania odwołuje się wielu badaczy, zauważyć jednak warto, iż niektóre z omawianych zwyczajów nie występują już współcześnie, inne natomiast - uznane za wymarłe - wciąż funkcjonują (Pośpiech 1987: 200-201, 222).

Bardzo ważnym efektem pracy badawczej było dla nas dotarcie do zwyczajów, których dotychczas nie zaprezentowano w literaturze przedmiotu. Zaliczyć do nich można np. wielkanocne tradycje: bramę wielkanocnq i krzyżoki z Borek Małych. Brama wielkanocna nie ma prawdopodobnie swego odpowiednika na terenie kraju, natomiast krzyżoki - obchód pól, spotykany jest np. w okolicach Łowicza. Nasza pierwsza rejestracja wiszącej bramy wielkanocnej w Borkach Małych miała miejsce 10 kwietnia 2016 roku (rok przed rozpoczęciem projektu Mapa), kiedy to Robert Garstka i Bogdan Jasiński udali się do tej miejscowości, odpowiadając na zaproszenie miejscowej nauczycielki, z którą nawiązano kontakt w 2015 roku. Przy tej okazji dowiedzieli się o kolejnych tradycjach, tj. męskiej grupie mikołajowej w Borkach Małych oraz goiku i szopce ołtarzowej w Borkach Wielkich, nieustępującej wielkością tej z katowickich Panewnik.

W późniejszym czasie zainteresowanie brama i krzyżokami ze strony innych instytucji kultury doprowadziło do wpisania tych tradycji na Krajową listę niematerialnego dziedzictwa kulturowego (2020 rok) oraz ukazania się w sieci kilku tekstów na ten temat ${ }^{8}$. Należy jednak zauważyć, o czym wspominali nam mieszkańcy ${ }^{9}$, iż żadna z tych instytucji przed rozpoczęciem realizacji Mapy nie wykazywała zainteresowania

6 Nie licząc tych opisujących wybrane przykłady obrzędowości dorocznej, ograniczonych do danego regionu lub bazujących dość często na przykładach z przeszłości (zob. Bazielich 2009).

7 Podstawę źródłową pracy Jerzego Pośpiecha tworzą opisy, materiały i opracowania oraz rezultaty badań terenowych prowadzonych przez autora w latach 1976-1982 w wybranych miejscowościach dawnych województw katowickiego i opolskiego (Pośpiech 1987: 9).

8 Martin Huć (mieszkaniec Borek Małych) przez kilka lat pisał o krzyżokach w gazecie lokalnej „Kulisy Powiatu Kluczbork - Olesno", natomiast jego pierwszy tekst zamieszczony w sieci ukazał się w 2015 r. 


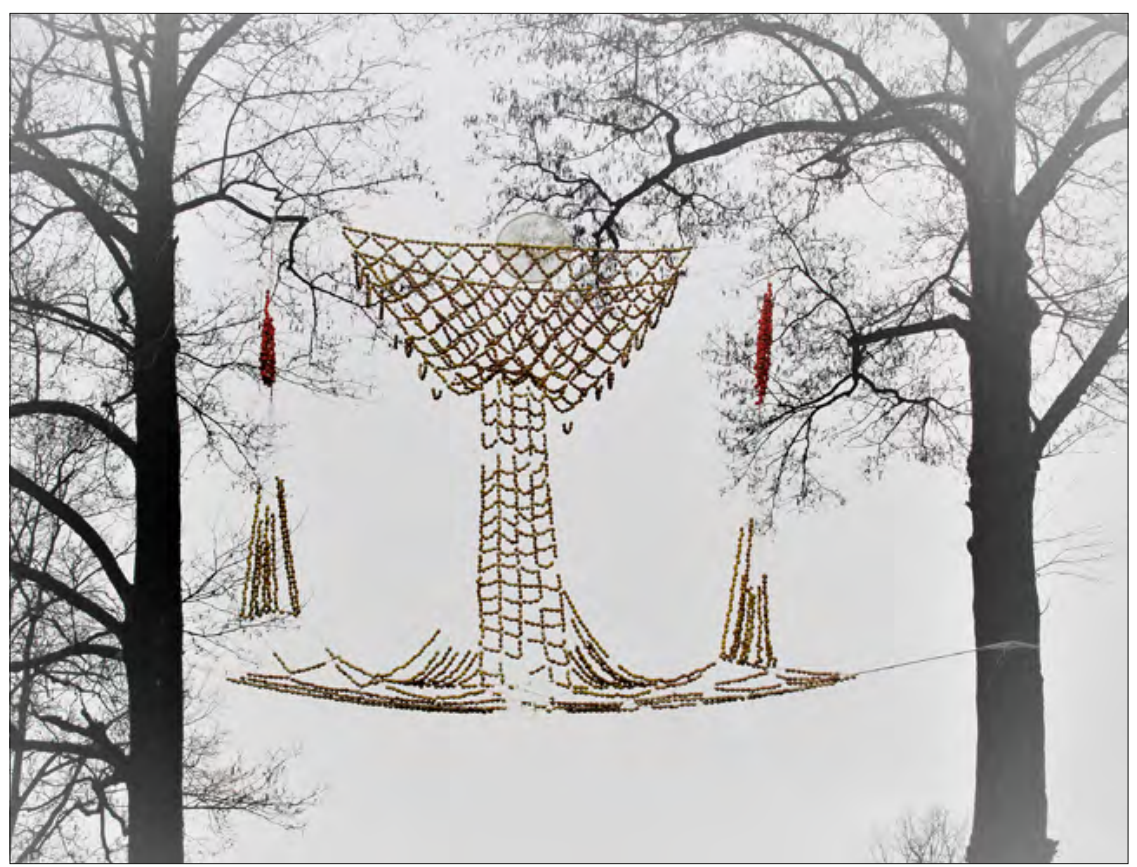

Fot. 1.

Brama wielkanocna; Borki Małe, 2016 r.

tą tradycją, czego dowodem jest np. brak informacji w źródłach (w tym książkowych) z wcześniejszych lat.

Z innych, nie mniej ważnych zwyczajów, wymienić należy: obchód chłopięcej grupy mikołajowej z Borek Wielkich, procesję ślubowaną w dniu św. Sebastiana w Gąsiorowicach (20 stycznia), marzanki ze Starych Siołkowic, wodzenie kozła w Popielowie, zwyczaj Józefka, „serca” na polach, stawianie maibaumu, wielkopiątkową procesję mężczyzn w Głogówku, klekotanie np. w Borkach Małych, KoIonowicach, Strzeleczkach, konną procesję w Wolęcinie, kulanie jaj w Kraskowie w województwie opolskim; zwyczaj Gospody z Katowic-Podlesia, golenie brody w Chwostku, wielkanocne męskie procesje w Świbiu, Wiśniczach i Szałszy, imieninowe wygrywki w Brennej i „palenie Judasza” w Babienicy w województwie śląskim. Ponadto wskazać można na tradycję układania kwietnych dywanów (chodników) ${ }^{10}$ związaną z uroczystościami Bożego Ciała, znaną w Raciborzu, jak i raciborskich wsiach (woj. śląskie), np. w Roszkowie, Krzanowicach, Samborowicach, Wojnowicach, Pietrowicach Wielkich i Cyprzanowie, a także we wsiach w pobliżu Strzelec Opolskich (woj. opolskie) - Kluczu, Olszowej, Rozmierzy, Zimnej Wódce i Zalesiu Śląskim. Ostatni terenowy wyjazd (03.06.2021 r.) wykazał kolejne

10 Poza roślinnością do tworzenia wzorów używa się także trocin, małych skrawków drewna oraz pia sku. W Pietrowicach Wielkich niektóre odcinki trasy dekorowane są długimi i wąskimi materiałowymi chodnikami. 


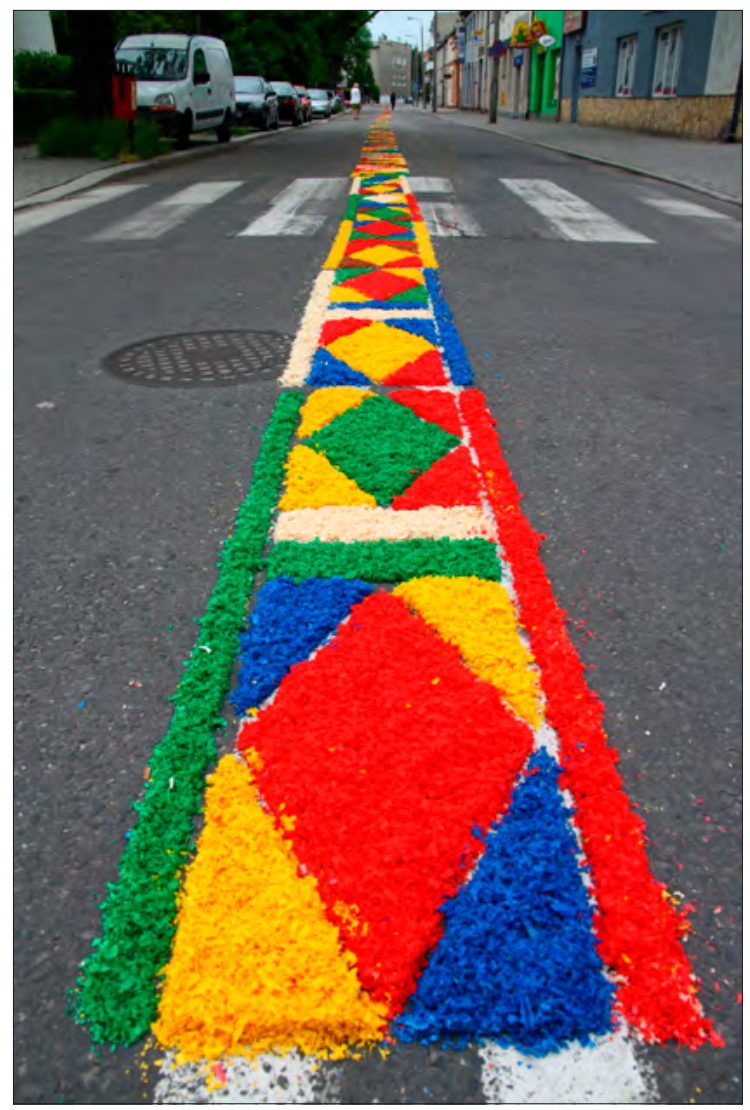

Fot. 2. Kwietny dywan wykonany z barwionych trocin; Racibórz, 2013 r. miejscowości, w których ta tradycja od wielu lat jest pielęgnowana. W powiecie raciborskim są to Krowiarki, Maków i Żerdziny, w powiecie wodzisławskim (woj. śląskie) Syrynia, Lubomia, Kokoszyce, Gorzyce, Gorzyczki i Uchylsko oraz Raków ${ }^{11}$ i Tłustomosty w powiecie głubczyckim (woj. opolskie) ${ }^{12}$. Pomimo iż tradycja układania kwietnych dywanów praktykowana jest w wymienionych miejscowościach od wielu lat ${ }^{13}$, to jednak nie jest tak szeroko znana jak ta w Spycimierzu ${ }^{14}$, która niejednokrotnie niesłusznie uznawana jest za jedyną w kraju (Dragan 2020: 40).

W literaturze przedmiotu spotkać można często opisy tradycji, np. palenie żuru, wielkopiątkowe obmywanie, dni krzyżowe, procesje w dniu św. św. Marka, Izydora, Urbana, Rocha czy stawianie krzyżyków z gałązek palmy wielkanocnej na polach, jednak w wielu przypadkach dotyczą one czasu przeszłego bez podkreślenia ich współczesnego oblicza. Dopełnieniem takiego przekazu jest skąpy materiał ikonograficzny lub wielokrotnie wykorzystywane w różnych opracowaniach to samo zdjęcie (często przedwojenne). Dlatego tak ważna jest stała obecność badacza w terenie, skutkująca bieżącą dokumentacją i analizą niematerialnego dziedzictwa.

Poniżej pragniemy zaprezentować niewielki wycinek pracy, przykłady odnalezionych w terenie tradycji. Część z nich to niezaprzeczalnie ważne odkrycia, dowodzące słuszności naszych badań terenowych.

11 W Rakowie tradycję zarzucono ok. 2015 r., natomiast współcześnie niewielkie kwietne dywany układane są jedynie przy kościele i ołtarzach na trasie procesji.

12 Rozpoznanie terenowe przeprowadził Robert Garstka.

13 Informacje uzyskane podczas rozmów i wywiadów kwestionariuszowych wskazują, iż zwyczaj ten znany jest (zależnie od miejscowości) od ponad 50 lub 100 lat. 


\section{Omówienie wybranych obrzędów i zwyczajów}

\section{Krzyżoki i brama wielkanocna}

W Borkach Małych (gm. Olesno) praktykowany jest unikatowy, i prawdopodobnie niespotykany w innych częściach Polski zwyczaj, którego genezy nie znają nawet najstarsi mieszkańcy. Przez cały Wielki Post krzyżoki - młodzi mężczyźni, kawalerzy - zbierają wydmuszki z jajek, z których następnie powstaje brama wielkanocna. Krzyżoków jest 12, czyli tylu, ilu było apostołów. Bramę, która każdorazowo ma inny kształt, tworzy się poprzez nawlekanie kilkuset wydmuszek na sznurki według przygotowanego wcześniej projektu. Kompozycja w 2018 roku składała się z 4700 wydmuszek. Wieczorem (ok. godziny 22:00) w Wielką Sobotę konstrukcję przenosi się ręcznie na ulicę Brodackiego i zawiesza między dwoma drzewami nad drogą pośrodku wsi, gdzie wisi do następnego rok. Później mężczyźni udają się do remizy, by wspólnie spożyć zrobioną przez siebie jajecznicę, po czym podążają do kościoła, skąd zabierają szarfy, kościelne chorągwie oraz figurę Chrystusa Zmartwychwstałego. Niesie ją mężczyzna, który w danym roku lub najbliższym czasie ma się żenić. Nad ranem, o godzinie 03:00, ruszają ze śpiewem i modlitwą na obchód pól wokół wioski, co ma zapewnić im ochronę oraz urodzaj. Po jej zakończeniu na krótko wracają do domu, następnie uczestniczą w procesji rezurekcyjnej, podczas której śpiewają pieśni wielkanocne wykonywane w trakcie obchodu pól.

\section{Pielgrzymka ślubowana w dniu św. Sebastiana}

Według wiernych, w XVII wieku, gdy w Gąsiorowicach (gm. Jemielnica) i okolicy panowała zakaźna choroba ${ }^{15}$, Duch Święty oświecił mieszkańców, aby udali się po pomoc z modlitwą błagalną do św. Sebastiana. Ludzie ruszyli procesyjnie do oddalonego o 3 kilometry kościoła parafialnego pw. Wniebowzięcia Najświętszej Marii Panny w Jemielnicy. Tam padli twarzą przed ołtarzem św. Sebastiana, błagając o wstawiennictwo i pomoc. Ich prośby zostały wysłuchane, a zaraza ustała. Dlatego też ślubowali, że każdego roku 20 stycznia będą pielgrzymować do jemielnickiej świątyni, dziękując św. Sebastianowi za ocalenie mieszkańców wsi. Przyrzeczenie to spełniają do dziś, podążając do Jemielnicy z feretronem (obraz religijny) przedstawiającym tego świętego. W drodze powrotnej wierni modlą się przy kilku przydrożnych kapliczkach. Przez cały rok obraz przechowywany jest w murowanej kaplicy w środku wsi. 


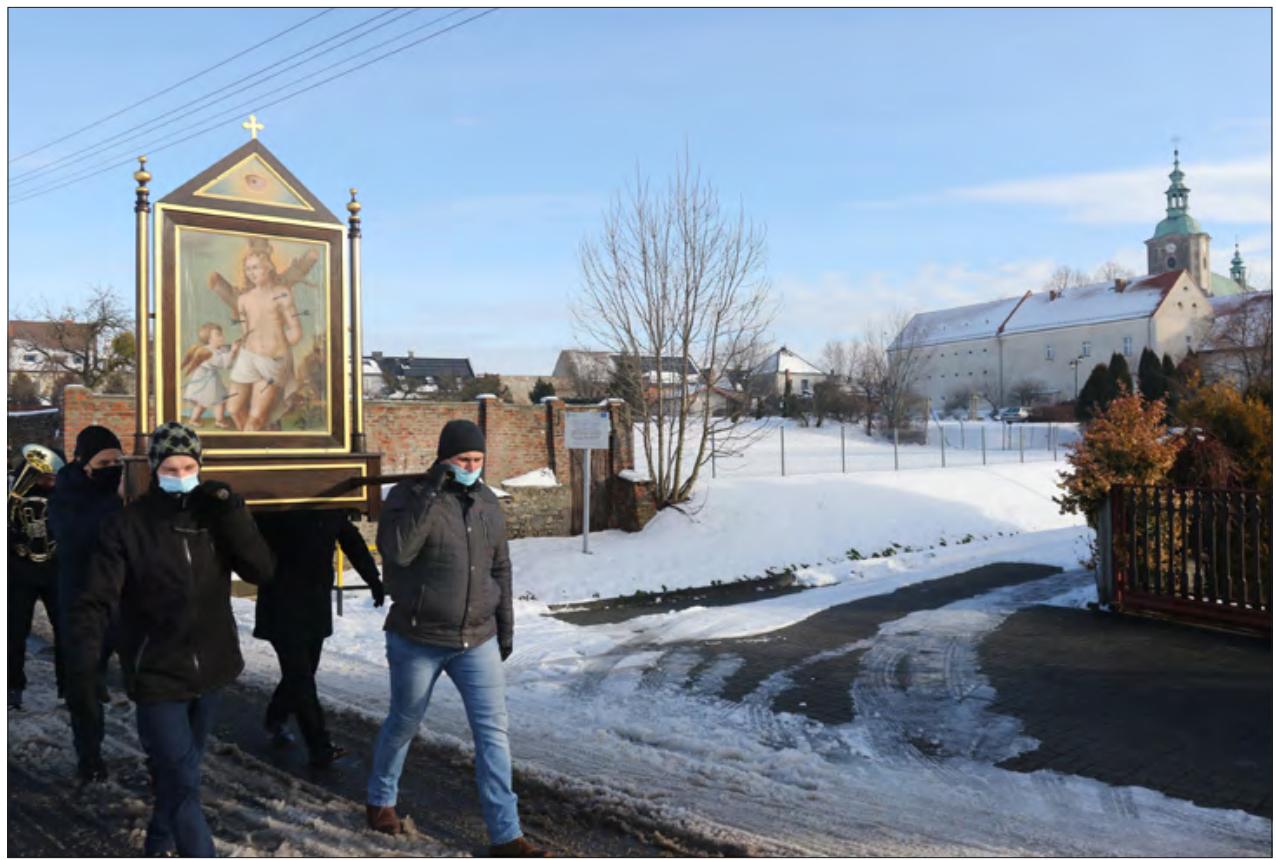

Fot. 3.

Procesja ślubowana w dniu św. Sebastiana; Gąsiorowice, 2021 r.

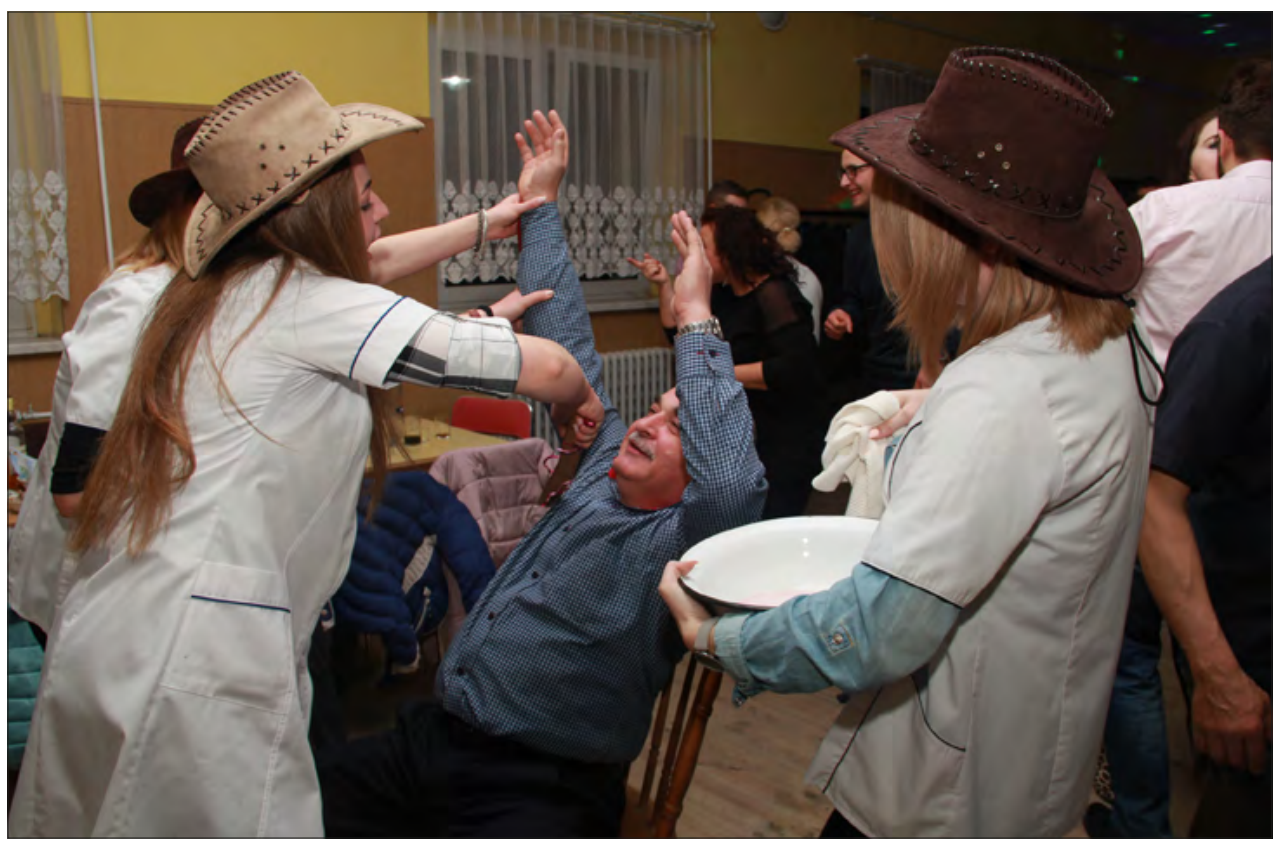

Fot. 4.

Golenie brody; Chwostek, 2018 r. 


\section{Golenie brody}

W Lisowie, Taninie i Chwostku (pow. lubliniecki) na wieczornej zabawie tanecznej, odbywającej się na zakończenie pochodu grupy ostatkowej z niedźwiedziem, praktykowany jest, zanikający i mało poznany, zwyczaj golenia brody. Około godziny 23:00 trzy młode dziewczyny (pierwotnie były to starsze gospodynie) podchodzą kolejno do tańczących par, przerywają taniec i sadzają mężczyznę na krześle. Następnie, przy użyciu drewnianej atrapy brzytwy, symulują golenie owłosienia w różnych miejscach ciała. Po krótkiej chwili mężczyzna wraca do swej partnerki i przerwanego tańca. Dziękując, składa pieniężny datek. Scena odgrywana jest kilkukrotnie, po czym dziewczęta wywożone są na taczkach poza salę. Niestety, osoby biorące udział w przedstawieniu oraz karnawałowej zabawie nie znają genezy i znaczenia tego zwyczaju. Można zauważyć, iż usunięcie na taczce osób z zabawy tanecznej przypomina ostatkowy zwyczaj „zabijania grajka” praktykowany niegdyś m.in. na Kujawach. Gdy zabawa dobiegała końca, sadzano grajka na taczce, wywożono z karczmy i obsypywano popiołem na znak zbliżającego się postu. W przypadku Chwostka na taczce są jednak kobiety niebędące muzykami (grajkami), a ponadto po tym akcie zabawa trwa jeszcze przez jakiśs czas.

\section{Marzanki i marzołki}

Strojenie marzanek w Starych Siołkowicach i Chróścicach, związane z okresem Wielkiego Postu, odbywa się w tzw. niedzielę czarna poprzedzającą Niedzielę Palmową. Marzanki to przystrojone lalki zamocowane do zielonych świerkowych gałęzi, ozdobionych kolorowymi wstążkami, wystawiane w oknie od strony szczytowej budynku lub w innych widocznych miejscach, np. na furtkach i balkonach. Informują one o obecności w domu panien, niezależnie od ich wieku. Współcześnie tę czynność wykonują rodzice, dawniej jednak to panny na wydaniu wystawiały lalki w oknach i mocowały je na gałązce lub czubku choinki bożonarodzeniowej. Jerzy Pośpiech wspominał o zwyczaju marzanek praktykowanym w Niedzielę Palmową:

W pod opolskim Dobrzeniu i okolicznych wsiach na przełomie XIX i XX w., po wieczornym obchodzie „tęgiego snopa słomy, ubranego w buciory” w Niedzielę Palmową, stawiano ponadto Marzanki na szczytach lub dachach zagród („aby nikt nie mógłje zrzucić”) (Pośpiech 1987: 159).

Autor nie rozwija tego wątku, dlatego też nie wiadomo, na jaką okazję wykonywano marzanki i czy była to forma podobna do tej znanej ze Starych Siołkowic. Uderzające podobieństwo do siołkowickiej tradycji można zaobserwować we Wręczycy Wielkiej (pow. kłobucki). Współcześnie dla podtrzymania tradycji członkinie tamtejszego Koła Gospodyń Wiejskich, a niegdyś dziewczęta, tydzień przed Niedzielą Palmową obchodzą miejscowość z goikiem - zielonym świerczkiem, na szczycie którego umocowana jest lalka ubrana na biało, z wianuszkiem na głowie, symbolizująca, zdaniem członkiń KGW, nowe życie lub zamążpójście. 


\section{Kulanie jaj}

Mało poznaną i opisaną tradycją jest zabawa polegająca na toczeniu jajek do dołka. Jeszcze w latach 50. i 60. XX wieku w wielkanocną niedzielę i lany poniedziałek w Kluczborku i na jego przedmieściach, a także we wsiach w pobliżu Kluczborka (np. w Lasowicach Wielkich, Kujakowicach Górnych, Chudobie, Chocianowicach, Borkowicach

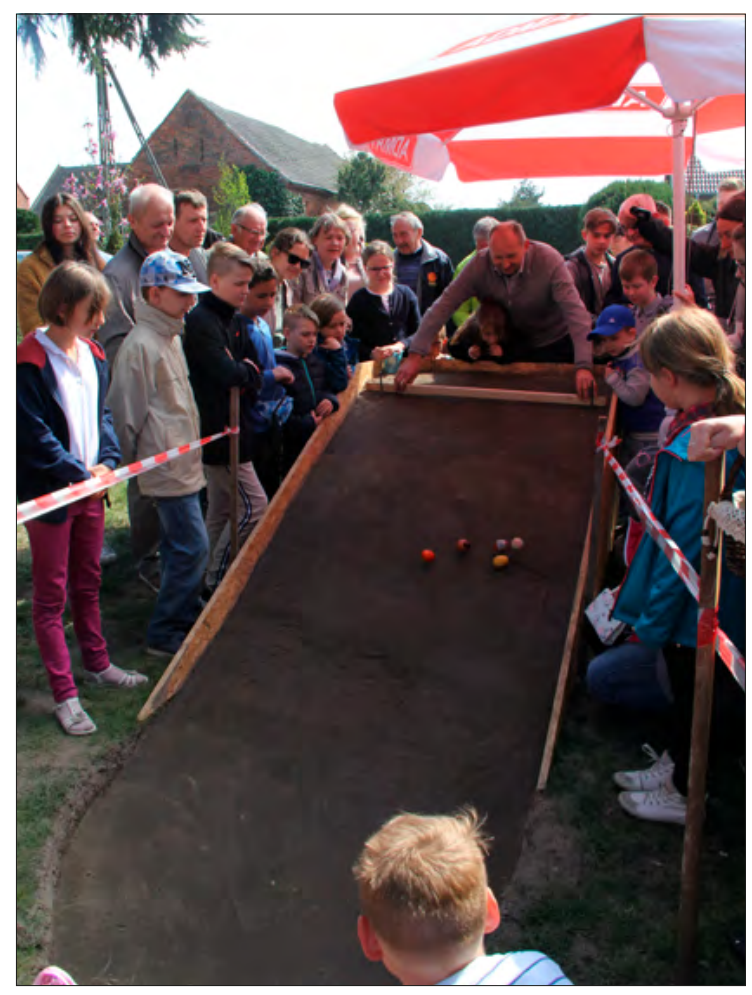

Fot. 5. Wielkanocna zabawa kulanie jaj; Krasków, 2019 r. oraz innych okolicznych wsiach) chłopcy oraz mężczyźni urządzali grę polegającą na kulaniu jajek z usypanej ziemnej górki-platformy) (Pośpiech 1987: 156). Istniały różne warianty tej gry. Wygrana przypadała osobie, której jajko potoczyło się najdalej lub dokulało najszybciej do mety, lub też trzykrotnie, jako pierwsze, trafiło do dołka - ducki. Nagrodą były jajka, które potoczyły się w innym kierunku (Pośpiech 1987: 200-201). Zapewne tak było w przypadku zabaw dziecięcych, jednakże dorośli mężczyźni grali na pieniądze, obstawiając, czyje jajko pierwsze stoczy się z górki. Nierzadko oszukiwano, używając jajka wypełnionego gipsem, które cięższe i stabilniejsze szybciej pokonywało wyznaczoną trasę. Podobne wydarzenia odbywały się jeszcze w latach 50. XX wieku, m.in. w Borkowicach, na placu przy domu sołtysa ${ }^{16}$. Niektórzy badacze uważają, iż jajka toczono również po desce, jednak (nieliczne) archiwalne zdjęcia nie potwierdzają tego (Pośpiech 1987: 200; Smolińska 2004: 71). Deska bowiem pełniła rolę belki startowej, za którą ustawiało się jajka. Po jej uniesieniu jajka swobodnie toczyły się w dół w stronę otworu. Wskazują na to badania etnograficzne przeprowadzone w Kraskowie w 2019 roku17.

Wśród badaczy nie ma zgodności co do daty będącej końcem występowania tej rozrywki. Jerzy Pośpiech wspomina o XIX wieku, Teresa Smolińska podaje początek XX wieku, natomiast Bogdan Jasiński - lata 60. XX wieku (Pośpiech 1987: 201; Smolińska 2004: 71; Jasiński 2017: 22). Badania terenowe oraz rozpoznanie środowiskowe

16 Relacja mieszkanki Borkowic, woj. opolskie (52 I.), październik 2019 r.

17 Obserwacja uczestnicząca i wywiad z mieszkańcami. 
(np. kontakt z sołtysami i parafią w Kraskowie) ku naszemu wielkiemu zaskoczeniu dowiodły, iż wydarzenie cieszące się dużym zainteresowaniem mieszkańców odbywa się nadal w Poniedziałek Wielkanocny w Kraskowie. Według relacji najstarszych mieszkańców, zwyczaj praktykowany jest nieprzerwanie od czasu zakończenia II wojny światowej. Corocznie usypywana jest mniejsza lub większa ziemna górka, natomiast od 2010 roku w razie niepogody gra odbywa się w domu parafialnym na specjalnie skonstruowanej platformie (Garstka, Lysko 2018: 157-158). W Kuniowie zabawa odbywała się jeszcze w latach 80. XX wieku. W pobliskich Chocianowicach ok. 2002 roku podjęto próbę reaktywacji tradycji, która jednak utrzymała się jedynie przez dwa lata i została zarzucona na skutek nikłego zainteresowania mieszkańców ${ }^{18}$.

\section{Zakończenie}

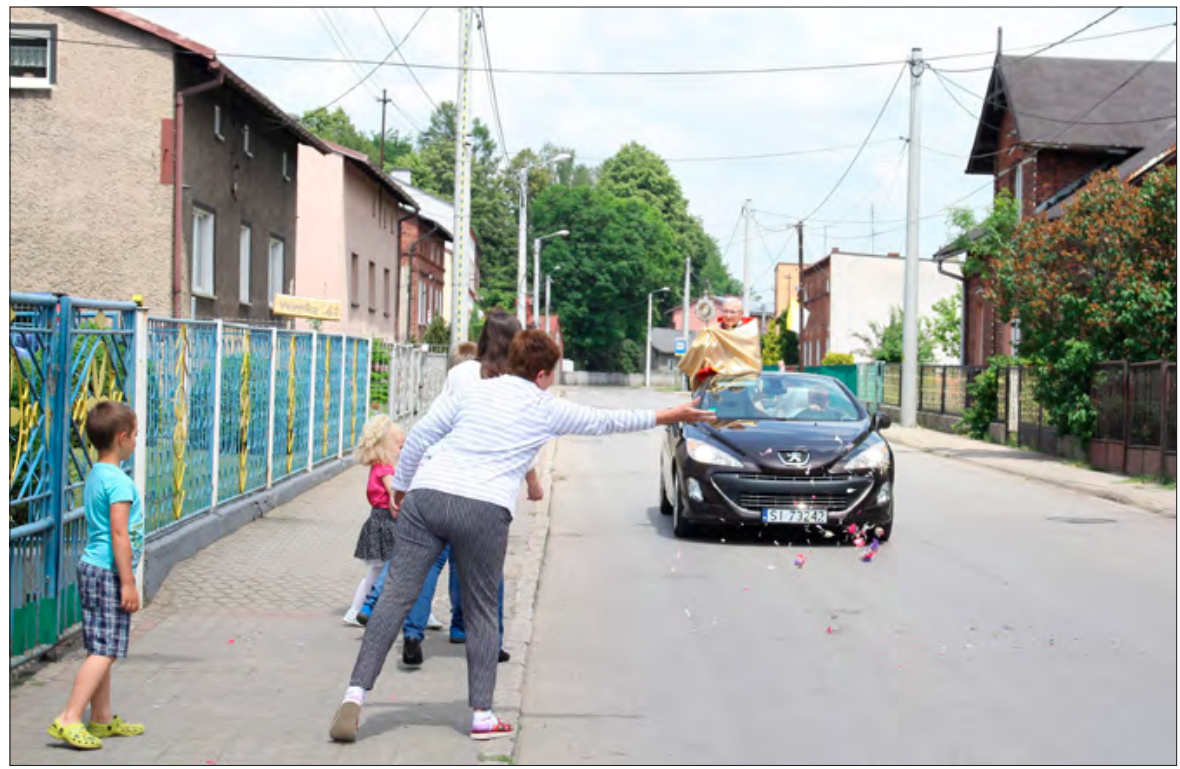

Fot. 6.

Kobiety sypiące kwiaty podczas uroczystości Bożego Ciała;

Siemianowice Śląskie - Przełajka, 2020 r.

Pomimo oficjalnie zakończonego projektu, nasza praca badawcza trwa nadal, a strona internetowa na bieżąco wzbogacana jest o nowe treści rejestrowane w terenie. Wśród nich są również te obserwowane w obecnym pandemicznym czasie, odbiegające całkowicie lub częściowo od tych z lat ubiegłych. Na zakończenie chcielibyśmy przytoczyć opis ukazujący aktualne przeobrażenia kulturowe:

18 Informacje uzyskane od mieszkańców podczas badań terenowych w pow. kluczborskim, październik 2019 r. 
W czerwcu natomiast procesje wiernych nie ruszyły na ulice, by uczcić uroczystość Bożego Ciała. Niektóre parafie całkowicie zrezygnowały z ich organizowania, inne ograniczyły się do procesji wokół świątyni (np. siemianowicki Bańgów czy Dąbrówka Wielka w Piekarach Śląskich). Nieliczni księża podjęli działania, by mimo wszystko w tym trudnym czasie dotrzeć do wiernych z Najświętszym Sakramentem. Przykładem jest parafia w Przełajce (dzielnicy Siemianowic Śląskich), gdzie kapłan jechał odkrytym samochodem ulicami miejscowości, błogosławiąc zebranych na trasie wiernych. Oba wydarzenia były przejmujące i znaczące. Ukazały bowiem, jak bardzo ważna w życiu katolika jest wiara i osobisty udział w wydarzeniach religijnych. Ponadto zastana sytuacja wymusiła na duchownych zastosowanie zastępczych środków i narzędzi dotarcia do wierzących, a dla tych ostatnich oznaczała podjęcie nowych form uczestnictwa w wydarzeniach religijnych oraz zmodyfikowała i ograniczyła kulturowe praktyki z nimi powiązane. Mówiąc wprost, pandemia w odróżnieniu od zmian, które następują stopniowo i są efektem procesu zmian cywilizacyjnych, społecznych i gospodarczych, „szokowo” wpłynęła na tegoroczny wizerunek kultury religijnej (Garstka, Gerlich, Lysko 2020: 155-156).

\section{Bibliografia}

Bazielich, B. (red.) (2009). Ludowe tradycje. Dziedzictwo kulturowe ludności rodzimej w granicach województwa śląskiego. Wrocław-Katowice: Polskie Towarzystwo Ludoznawcze, Muzeum Śląskie w Katowicach.

Dragan, J. (2020). Spycimierskie Boże Ciało - tradycja i współczesność. W: K. Smyk (red.), Procesja Bożego Ciała z tradycją kwietnych dywanów w Spycimierzu. Raport z badań i rekomendacje do planu ochrony (s. 37-48). Uniejów-Wrocław: Miejsko-Gminna Biblioteka Publiczna w Uniejowie.

Garstka, R. (2013). Świat obok nas. Obrzędowość doroczna w województwie śląskim. Katowice: Regionalny Ośrodek Kultury w Katowicach.

Garstka, R., Gawlik, B.i Skonieczna-Gawlik, D. (2016). Tropem Badaczy Zagłębia Dąbrowskiego. Katowice: Regionalny Instytut Kultury w Katowicach.

Garstka, R., Gerlich, M.G.i Lysko A. (2020). Sacrum i jego otoczka kulturowa w realiach górnośląskich. Między dawnymi a nowymi czasy. Katowice: Instytut Myśli Polskiej im. Wojciecha Korfantego w Katowicach.

Garstka, R., Lysko, A. (2018). Czas niezwykły. Obrzędowość doroczna na Górnym Śląsku. Katowice: Regionalny Instytut Kultury w Katowicach.

Jasiński, B. (2017). Opolskie kroszonki. Opole: Muzeum Wsi Opolskiej, Związek Śląskich Rolników w Opolu. Pośpiech, J. (1987). Zwyczaje i obrzędy doroczne na Śląsku. Opole: Instytut Śląski w Opolu.

Smolińska, T. (2004). Tradycyjne zwyczaje i obrzędy śląskie. Wypisy. Opole: Wydawnictwo Uniwersytetu Opolskiego. 


\section{Spis fotografii}

Fot.1. Brama wielkanocna. Borki Małe, 2016 r. Fot. R. Garstka.

Fot.2. Kwietny dywan wykonany z barwionych trocin. Racibórz, 2013 r. Fot. R. Garstka.

Fot.3. Procesja ślubowana w dniu św. Sebastiana. Gąsiorowice, 2021r. Fot. R. Garstka.

Fot.4. Golenie brody. Chwostek, 2018 r. Fot. R. Garstka.

Fot.5. Wielkanocna zabawa kulanie jaj. Krasków, 2019 r. Fot. A. Lysko.

Fot.6. Kobiety sypiące kwiaty podczas uroczystości Bożego Ciała. Siemianowice Śląskie - Przełajka, 2020 r. Fot. R. Garstka.

\section{Streszczenie}

Niniejszy tekst prezentuje założenia i efekty etnograficznego projektu badawczego Mapa Obrzędowa Górnego Śląska, zrealizowanego przez Regionalny Instytut Kultury w Katowicach (obecnie Instytut Myśli Polskiej im. Wojciecha Korfantego). W artykule odnajdujemy informacje dotyczące wirtualnej mapy, na której umieszczono ponad 370 wpisów ilustrujących obrzędy i zwyczaje na historycznej ziemi górnośląskiej. Dalej mowa jest o charakterystyce, specyfice i istotności podjętych badań oraz ich wynikach. Opracowanie kończy się opisem kilku praktyk kulturowych zarejestrowanych w ramach badań (które znane do tej pory były głownie w lokalnych społecznościach) oraz przykładem przeobrażenia przebiegu uroczystości Bożego Ciała w czasach pandemii.

Słowa klucze: obrzędy doroczne, mapa, zwyczaj, badania terenowe, dokumentacja fotograficzna, Górny Śląsk

\section{Summary}

This text presents the assumptions and effects of the ethnographic research project Map of the Rites of Upper Silesia, carried out by the Regional Institute of Culture in Katowice (currently the Institute of Polish Thought). The article contains information about a virtual map with over 370 entries illustrating the rituals and customs practised in the historical Upper Silesia region. The text also mentions the characteristics, specificity and relevance of the research undertaken and its results. The text ends with a description of several unique cultural practices recorded in the research (so far known mainly in local communities) and an example of the transformation of the course of Corpus Christi celebrations in the times of the pandemic.

Keywords: annual rites, map, custom, field research, photographic documentation, Upper Silesia

Translated by Authors 



\section{na inny temat}


